\title{
Upaya Meningkatkan Pengetahuan Sains Melalui Pendekatan Eksplorasi Lingkungan Sekitar di TK Putra I Kota Jambi Kelompok B Tahun Ajaran 2016/2017
}

\author{
Delima $^{1}$
}

\begin{abstract}
Abstrak: Penelitian ini bertujuan untuk meningkatkan pengetahuan anak didik TK Putra I Kota Jambi dalam pengetahuan sainsnya melalui metode atau pendekatan eksplorasi lingkungan sekitar. Penelitian dilakukan dengan tindakan kelas dengan metode kuantitatif dan kualitatif. Subjek penelitiannya anak didik TK Putra I Kota Jambi Kelompok B yang terdiri dari 19 anak. Teknik analisis data yang digunakan adalah deskriptif persentatif dan deskriptif aktivitas anak didik. Validitas data menggunakan validitas isi (content validity). Hasil penelitian menunjukkan bahwa Eksplorasi Lingkungan Sekitar dapat meningkatkan kemampuan sains anak didik terbukti dari kenyataan bahwa kondisi awal sebelum dilakukan tindakan, rata-rata persentasi kemampuan sains anak sebesar $31 \%$. Kemudian setelah dilakukan tindakan penelitian kelas melalui Eksplorasi Lingkungan Sekitar rata-rata persentasi kemampuan sains anak meningkat menjadi $41 \%$. Berikutnya pada siklus II rata-rata persentasi kemampuan sains anak meningkat sebesar 59\% dan terakhir pada siklus III rata-rata persentasi kemampuan sains anak sudah mencapai target sesuai dengan yang diharapkan peneliti yaitu sebesar $83 \%$. Kesesuaian penggunaan metode pembelajaran akan menentukan tercapainya tujuan pendidikan. Semua tujuan pendidikan yang ingin dicapai selayaknya sudah tersusun dalam kurikulum sebagai alat yang harus dimiliki guru dalam menjalankan tugasnya. Sedangkan cara menggunakan alat akan sangat bergantung pada kompetensi guru. Kemampuan guru dalam menghubungkan tujuan pendidikan dengan cara mencapainya tidak lepas dari tiga langkah penting. Tiga langkah penting ini meliputi perencanaan, pelaksanaan dan evaluasi. Penentuan metode pembelajaran terjadi pada tiga proses langkah penting tersebut. Penentuan metode eksplorasi lingkungan sekitar untuk meningkatkan pengetahuan sains adalah cara yang tepat dan terbukti berhasil dalam praktik Penelitian Tindakan Kelas di TK Putra I Kota Jambi.
\end{abstract}

Kata kunci : Pendekatan Eksplorasi Lingkungan Sekitar, Sains

Abstract: This study aims to improve the knowledge of Putra I Kota Jambi Kindergarten students in their scientific knowledge through methods or approaches to the exploration of the surrounding environment. The research was conducted by class action with quantitative and qualitative methods. The research subject was a student of Putra I TK Jambi City Group B consisting of 19 children. The data analysis technique used is descriptive percentative and descriptive of student activities. Data validity uses content validity. The results of the study showed that the Exploration of the Surrounding Environment can improve students' scientific abilities as evidenced by the fact that the initial conditions prior to the action, the average percentage of children's scientific ability was $31 \%$. Then after the classroom action research was carried out through Environmental Exploration, the average percentage of children's scientific ability increased to $41 \%$. Next in the second cycle the average percentage of children's scientific abilities increased by 59\% and the last in the third cycle the average percentage of children's scientific ability had reached the target in accordance with what was expected by the researchers, amounting to 83\%. Suitability for the use of learning methods will determine the achievement of educational goals. All educational goals that want to be achieved should have been arranged in the curriculum as a tool that must be owned by the teacher in carrying out their duties. While how to use the tool will depend on the competence of the teacher. The ability of the teacher to connect the goals of education by achieving it cannot be separated from three important steps. These three important steps include planning, implementation and evaluation. Determination of learning methods occurs in three processes of these important steps. Determination of the method of exploration of the surrounding environment to improve science knowledge is the right way and proven successful in the practice of Classroom Action Research in Putra I TK Jambi City.

Keywords: Environmental, Exploration Approach, Science

\section{PENDAHULUAN}

Masa kanak-kanak merupakan sebuah periode penaburan benih, pembuatan pondasi yang disebut juga sebagai periode pembentukan watak, kepribadian dan karakter agar mereka mampu berdiri tegar dalam meniti kehidupan. Jika anak di didik dengan baik maka hasilnya pun anak akan menjadi baik. Namun

\footnotetext{
${ }^{1}$ Guru Taman Kanak-Kanak Putra I Kota Jambi
} 
sebaliknya jika mendidiknya keliru dan tidak bertanggung jawab, maka akan menghasilkan generasi penerus yang tidak baik dan tidak bisa diharapkan oleh bangsa. Oleh karena sudah menjadi tanggung jawab para pendidik untuk dapat mendidik, membimbing dan mengarahkan anak-anak kearah yang lebih baik.

Ki Hajar Dewantara (1889-1959), pendiri Taman Siswa menyelenggarakan pendidikan taman kanakkanak yang disebut "Taman Indria" Di sekolah ini anak usia 4-5/6 tahun mendapat tempat untuk mengembangkan potensi-potensi yang dimilikinya dalam berbagai bentuk kegiatan belajar dalam bermain. Bentuk kegiatan ini diwujudkan dalam berbagai ekspresi diri secara kreatif. (Martini Jamaris, 2003 : 3). Dari pengertian yang dikemukakan di atas menjelaskan bahwa anak usia taman kanak-kanak ada dalam usia 4 tahun dan 5 tahun dengan rentang usia sampai 6 tahun. Usia ini sering disebut sebagai usia prasekolah. Usia prasekolah merupakan masa persiapan untuk memasuki jenjang pendidikan selanjutnya yaitu pendidikan formal di sekolah dasar.

Menurut Piaget (Masitoh dkk, 2007 : 5.4) bahwa anak belajar lebih banyak melalui bermain dan melakukan percobaan dengan objek-objek nyata dan pengalaman nyata. Peran guru sebagai fasilitator dalam pelaksanaan pendidikan untuk anak usia dini harus mampu memberikan kemudahan kepada anak untuk mempelajari berbagai hal yang terdapat dalam lingkungannya.

Dunia anak adalah dunia yang penuh dengan canda tawa dan kegembiraan, sehingga orang dewasa akan ikut terhibur dengan hanya melihat tingkah polah mereka. Menurut Masitoh (2007 : 1.7) anak usia Taman Kanak-kanak yakni yang terentang antara usia empat sampai dengan enam tahun.

Imajinasi merupakan proses menciptakan suatu objek/kejadian tanpa didukung oleh data yang nyata. Lewat imajinasi manusia bisa menciptakan suatu penemuan baru guna kepentingan masa depan atau hal-hal fantastik lainnya (Ayahbunda, 2002 : 56). Sains bermanfaat bagi anak karena dapat menciptakan suasana yang menyenangkan serta dapat menimbulkan imajinasi-imajinasi pada anak yang pada akhirnya dapat menambah pengetahuan anak secara alamiah.

Anak prasekolah pada dasarnya membutuhkan kesempatan untuk mengungkapkan cara pandangnya secara bebas, sehingga fantasi-fantasi yang dipikirkan dapat diekspresikan secara bebas pula (Martini Jamaris, 2003: 54).

Seperti para ilmuwan, anak membutuhkan keterampilan bagaimana caranya menggunakan kemampuan mengobservasi, mengklasifikasi, mengukur, memprediksi, melakukan eksperimen dan berkomunikasi seperti pada saat dia menjelajah (Yuliani Nurani Sujiono, 2006 : 12.13-12.15)

Pada waktu anak melakukan pengamatan/observasi, anak belajar menggunakan fungsi panca inderanya seoptimal mungkin seperti melihat, mendengar, mencium, merasa dan meraba (Martini Jamaris, 2003 : 44). Merupakan kemampuan yang sangat penting untuk mengerti dan memahami tentang isi dunia baik tumbuhan maupun teknologi. Anak belajar mengklasifkasikan dengan cara yang mudah, seperti saat mencari persamaan dan perbedaan. Dalam melakukan kegiatan mengklasifikasi benda, objek dan peristiwa, anak tidak hanya mengamati tetapi juga berpikir sehingga ia dapat memilih dan melatakkan benda, objek/peristiwa sesuai dengan klasifikasinya (Martini Jamaris, 2003 : 45).

Menurut pendekatan High scope (Masitoh, dkk, 2007 : 5.4) bahwa anak memiliki potensi untuk mengembangkan pengetahuannya melalui interaksi dengan lingkungannya. Lingkungan belajar harus mendukung aktivitas belajar.

Lingkungan alam atau lingkungan fisik adalah segala sesuatu yang sifatnya alamiah, seperti sumber daya alam (air, hutan, tanah, batu-batuan), tumbuh-tumbuhan dan hewan (flora dan fauna), sungai, iklim, suhu dan sebagainya. J.J Rousseau (Widarmi D Wijana, 2008 : 2.30) selalu mengadvokasi agar anak kembali ke alam dan melakukan pendekatan-pendekatan untuk membelajarkan anak lewat alam.

Untuk merealisasikan hal tersebut, maka mendidik anak pada usia dini merupakan upaya yang melahirkan generasi berkualitas tinggi. Masa prasekolah inilah yang berperan secara unik dalam pertumbuhan dan perkembangan seorang anak. Menumbuhkan rasa bersahabat dengan alam dan berpengalaman dengan hal yang baru, maka akan membuat anak mempunyai pemikiran yang luas dan mudah memecahkan masalah.

Anak adalah ilmuwan alamiah, karena melalui panca inderanya anak mampu mengamati fenomena alam disekelilingnya. Untuk mendorong hal tersebut banyak cara yang dapat dilakukan orang dewasa dalam membantu anak agar dapat tumbuh menjadi ilmuwan muda yang kreatif dan inovatif serta mempunyai pengalaman hidup yang bermakna. 
Seiring dengan perkembangan ilmu pengetahuan dan teknologi yang semakin canggih saat ini, maka diperlukan berbagai kegiatan yang dapat dilakukan untuk memahami gejala alam agar memiliki kebermaknaan bagi anak didik. Tidak dapat dipungkiri bahwa kegiatan sains belum sepenuhnya dapat dilakukan dan belum sepenuhnya memperoleh dukungan baik dari orang tua maupun pendidik.

Perkembangan sains dan teknologi perlu diperkenalkan kepada anak sejak dini, diharapkan agar kelak sebagai masyarakat dan generasi muda mampu melaksanakan dan mengembangakan potensi diri serta tanggap pada masalah-masalah yang aktual dan berkaitan dengan lingkungan dan teknologi. Dalam UU No. 20 Th. 2003 tentang sistem pendidikan nasional pasal 3 dirumuskan bahwa tujuan pendidikan nasional berfungsi "Mengembangkan kemampuan dalam watak pera daban bangsa yang bermartabat dalam rangka mencerdaskan kehidupan bangsa bertujuan untuk berkembangnya potensi peserta didik agar menjadi manusia yang beriman dan bertaqwa kepada Tuhan Yang Maha Esa, berakhlak mulia, sehat, berwawasan luas, kreatif, mandiri dan menjadi warga negara yang demokratis dan bertanggung jawab. Keberhasilan pendidikan nasional merupakan tujuan utama bangsa Indonesia, salah satu faktor penunjang pendidikan yaitu dengan menciptakan suasana Kegiatan Belajar Mengajar (KBM) yang kondusif dan menyenangkan sehingga siswa dengan mudah dapat menyerap materi pelajaran yang telah disampaikan.

Pembelajaran sains memang tidak tercantum di dalam kurikulum TK,tetapi hal itu bukan berarti bahwa sains tidak ada di TK. Sains di TK tetap ada dan terpadu dengan bidang lainnya hampir di setiap tema. Pengenalan sains untuk anak TK jika dilakukan dengan benar akan mengembangkan secara bertahap kemampuan berpikir logis yang belum di miliki anak.

Permainan sains dapat memberikan pengaruh pengaruh terhadap perkembangan sosio-emosional, fisik, kreativitas dan perkembangan kognitif. Tahapan di setiap usia kronologis dan perkembangan sangat menentukan jenis dan tingkat kesulitan dalam permainan sains. Itu berarti permainan sains haruslah diberikan dari hal-hal yang sederhana menuju ke tingkatan yang lebih kompleks. Pada dasarnya kegiatankegiatan dalam konsep sains dapat dipelajari melalui pengalaman sehari-hari yang nyata dan sederhana. Suasana yang menarik dan menyenangkan akan memotivasi anak untuk terus menerus mancari jawaban terhadap apa yang ia pikirkan dan ingin ia buktikan.

Sains merupakan kegiatan bereksperimen atau percobaan melalui observasi untuk mengetahui sesuatu. Eksperimen adalah pintu yang paling asyik untuk memasuki dunia sains. Kalau dilakukan di masa kanakkanak, maka ia berpotensi besar untuk menjadi memori masa kecil yang menyenangkan. Saat bertambah usia dan tiba waktunya mereka mendalami sains dengan disiplin yang lebih "serius", maka memori masa kanak-kanak itu akan bermetamorfosis menjadi sebentuk persepsi bahwa sains itu menyenangkan. Tatkala sains menjadi menyenangkan, maka energi yang besar bersemanyam di dalam diri anak-anak. Ketakutan dan kecemasan bahwa sains itu menyeramkan dapat dipastikan akan terkubur dalam-dalam. Kalaulah itu terjadi, sungguh berbahagialah bangsa ini. Mimpi untuk menjejarkan diri dengan bangsa-bangsa dunia dalam hal sains dan teknologi bukan lagi bagai pungguk merindukan bulan.

Di TK Putra I Kota Jambi pengetahuan sains anak mengenai lingkungan sekitarnya kurang berkembang. Hal ini disebabkan karena kurangnya pengalaman anak dalam hal pengetahuannya mengenai lingkungan secara nyata. Juga karena kurangnya keinginan anak untuk mencoba dan memecahkan masalah mengenai sains.

Pengetahuan sains anak yang kurang memuaskan juga dikarenakan guru dalam kegiatan pembelajaran banyak yang dilakukan di dalam kelas. Selain itu juga guru dalam penyampaian materi bersifat teori atau cenderung ceramah dan tidak menggunakan benda kongkrit sebagai medianya. Hal ini membuat guru resah, apalagi hasil belajar yang kurang memuaskan terutama dalam pengungkapan konsep sains anak. Melihat kondisi yang ada maka diadakan beberapa upaya perbaikan salah satunya yaitu dengan eksplorasi lingkungan sekitar. Dengan mengembangkan pengetahuan sains melalui pendekatan eksplorasi lingkungan sekitar diharapkan anak dapat mempunyai pengetahuan dan pengalaman yang mengasyikkan dan berguna bagi kehidupannya.

Anak sangat dekat dengan lingkungan, segala sesuatu yang ada di lingkungan anak bisa digunakan sebagai media pengetahuan dan sains. Fried dan Hademenos (2005 : 1) mengungkapkan bahwa Sains adalah sistem terorganisasi untuk mempelajari secara sistematik aspek-aspek tertentu dari alam. Ruang lingkup sains terbatas pada hal-hal yang dapat dipahami oleh indera (penglihatan, sentuhan, pendengaran, dan lainlain). Secara umum, sains menekankan pendekatan objektif terhadap fenomena-fenomena yang dipelajari. 
Pertanyaan-pertanyaan mengenai alam yang diajukan oleh para siantis cenderung untuk menekankan pada bagaimana berbagai hal terjadi dan bukannya mengapa hal-hal itu terjadi. Metode saintifik diterapkan bagi masalah-masalah yang dirumuskan oleh orang yang terlatih dalam disiplin ilmu tertentu.

Menurut Anna Poedjiadi dan suwarma (2007 : 2.9) mendefinisikan sains merupakan sekelompok pengetahuan tentang objek atau fenomena alam yang diperoleh dari hasil pemikiran dan penelitian para ilmuwan yang dilakukan dengan keterampilan bereksperimen menggunakan metode ilmiah.

Sedangkan menurut Sujiono dkk (2006 : 12.2) menyatakan bahwa hakikat pengembangan sains di Taman Kanak-kanak adalah kegiatan belajar yang menyenangkan dan menarik dilaksanakan melalui bermain melalui pengamatan, penyelidikan dan percobaan untuk mencari tahu atau menemukan jawaban tentang kenyataan yang ada di dunia sekitar.

Secara khusus sains di Taman Kanak-kanak (Yuliani Nurani Sujiono, 2006 : 12.3-12.4) bertujuan agar anak memiliki kemampuan: 1) Dari mengamati perubahan-perubahan yang terjadi disekitanya, seperti perubahan antara pagi, siang dan malam ataupun perubahan dari benda padat menjadi cair; 2) Melakukan percobaan-percobaan sederhana, seperti biji buah yang ditanam akan tumbuh atau percobaan pada balon yang diisi gas akan terbang bila di lepaskan ke udara; 3) Melakukan kegiatan membandingkan, memperkirakan, mengklasifikasikan serta mengkomunikasikan tentang sesuatu sebagai hasil sebuah pengamatan yang sudah dilakukannya. Seperti badan sapi lebih besar dari badan kambing, tetapi badan sapi lebih kecil dari badan gajah; 4) Meningkatkan kreativitas dan keinovasian, khususnya dalam bidang ilmu pengetahuan alam, sehingga anak akan dapat memecahkan masalah yang dihadapinya. Seperti anak dapat menjangkau buah jambu di atas pohon dengan cara menyambung dua batang kayu yang pendek sehingga menjadi lebih panjang dan dapat dipergunakan sebagai alat bantu dalam bekerja.

Untuk memenuhi rasa keingintahuannya melalui eksplorasi dibidang sains, anak mencoba memahami dunianya melalui pengamatan, penyelidikan dan percobaan. Tujuan secara umum permainan sains di Taman Kanak-kanak (Yuliani Nurani Sujiono, 2006 : 12.3) bertujuan agar anak mampu secara aktif mencari informasi tentang apa yang ada di sekitarnya.

Diharapkan berbagai jenis permanan sains tidak hanya dikembangkan dan di variasi oleh guru TK, tetapi juga adanya partisipasi aktif orangtua di rumah. Secara khusus manfaat sains bagi guru dan orangtua (Yuliani Nurani Sujiono,2006 : 12.4-12.5).

Beberapa anak berkembang dengan lancar, bertahap dan langkah demi langkah, sedangkan yang lain bergerak dengan kecepatan yang melonjak (Hurlock 1997 : 35).

Kegiatan sains dapat merangsang aspek perkembangan seperti sosio-emosional, fisik dan kreativitas di mana hal ini akan ikut terbangun dalam setiap aktivitas sains yang dilakukan anak bersama dengan guru atau orangtuanya. Pengaruh sains pada berbagai aspek perkembangan (Yuliani Nurani Sujiono,2006 :12.8).

\section{METODE PENELITIAN \\ Tempat dan Waktu Penelitian \\ Tempat Penelitian}

Penelitian tindakan ini dilakukan di Taman Kanak-kanak Putra I Kota Jambi. Peneliti memilih Taman Kanak-kanak Putra I Kota Jambi sebagai tempat penelitian karena tempat peneliti bertugas sebagai pendidik di Taman Kanak-kanak tersebut. Dan anak Taman Kanak-kanak Putra I dalam pengetahuan sains kurang berkembang. Dengan melakukan penelitian perbaikan kegiatan di Taman Kanak-kanak tempat peneliti sendiri, tentunya akan memudahkan bagi peneliti dalam memperoleh data dan sekaligus hasil perbaikan akan langsung dirasakan.

\section{Waktu Penelitian}

Penelitian ini dilakukan pada tahun 2016/2017. Pada persiapan penulisan laporan perbaiakan pembelajaran, kegiatan penelitian dimulai dari persiapan penyusunan rencana perbaikan pembelajaran/kegiatan, menyusun instrument penelitian, pengumpulan data, penentuanan pembahasan masalah hingga laporan hasil penelitian.

\section{Subjek Penelitian}

Penelitian kegiatan ini dilakukan pada Taman Kanak-kanak Puta I Kelompok B dengan jumlah anak 19 yang terdiri dari 11 anak perempuan dan 8 anak laki-laki. Anak-anak sangat menyukai semua kegiatan 
yang diberikan guru, namun ada kecenderungan mereka pada kegiatan pengembangan sains kurang berminat, sehingga tujuan kegiatan belum dapat dicapai dengan optimal sebagaimana harapan guru.

\section{Sumber Data}

Sumber data adalah subjek dari mana data dapat diperoleh (Arikunto, 2002:114). Dalam penelitian tindakan kelas ini, sumber datanya terdiri atas:

a. Person, yakni sumber data yang berasal dari siswa dan guru Taman Kanak-kanak Pertiwi Kenjer, Kecamatan Kertek, Kabupaten Wonosobo.

b. Place, yakni sumber data yang menyajikan tampilan berupa keadaan diam dan bergerak. Sumber data yang diam seperti ruang kelas TK Putra I Kota Jambi, lingkungan sekitar TK Putra I Kota Jambi , kelengkapan alat dan sejenisnya. Sedangkan sumber data yang bergerak, yakni aktivitas guru dan siswa TK Putra I Kota Jambi dalam proses pembelajaran yang menerapkan konsep sains.

\section{Teknik Pengumpulan Data \\ Observasi}

Teknik ini di gunakan untuk mengamati pelaksanaan dan perkembangan pengetahuan sains yang dilakukan guru dan anak pada kegiatan eksplorasi lingkungan sekitar. Observasi/pengamatan merupakan cara untuk mengetahui apa saja yang dilakukan anak. Perilaku, sifat, keinginan, kesenangan, kemampuan, dan tahap perkembangan dapat diketahui melalui pengamatan terhadap anak. Catatan pengamatan terhadap anak tersebut dapat dijadikan masukan bagi guru mengenai perkembangan anak (Widarni D Wijana,2008 : 6.5). Observasi dilakukan terhadap anak-anak, guru dan proses kegiatan belajar. Selain itu observasi juga dilakukan terhadap dokumen-dokumen yang dapat membantu pemecahan masalah. Dengan observasi peneliti dapat memantau proses dan dampak perbaikan yang direncanakan. Adapun observasi yang digunakan dalam penelitian ini adalah observasi sistematis (pengamat menggunakan pedoman sebagai instrumen pengamatan).

\section{Dokumentasi}

Dokumentasi ini digunakan untuk memperoleh data dari seluruh dokumentasi yang ada. Dokumentasi dalam Kamus Besar Bahasa Indonesia (KBBI) didefinisikan sebagai sesuatu yang tertulis, tercetak atau terekam yang dapat dipakai sebagai bukti atau keterangan. Data dokumentasi pada penelitian ini adalah fotofoto kegiatan pembelajaran, lembar pengamatan anak, lembar observasi guru dan anak.

\section{Validitas Data}

Dalam penelitian ini menggunakan validitas isi. Validitas isi (content validity) adalah validitas instrumen yang memiliki kandungan isi butir butir soal item pertanyaan yang dibuat sesuai dengan topik penelitian dan bisa menggali jawaban responden sesuai dengan permasalahan yang sudah dirumuskan. Disini peneliti telah menentukan kisi-kisi materi yang akan disampaikan dalam rangka mencapai aspek indikator yang ingin dicapai.

\section{Analisis Data}

Analisis data adalah suatu cara menganalisis data yang diperoleh selama peneliti mengadakan penelitian. Penelitian ini termasuk penelitian kuantitatif dan kualitatif. Secara kuantitatif data yang terkumpul dianalisa secara diskriptif presentase. Tingkat perubahan yang terjadi diukur dengan persen. Jumlah anak yang mampu mencapai indikator keberhasilan dibagi jumlah anak seluruh yang diteliti dikalikan seratus persen, maka diketahui presentase dari tingkat keberhasilan tindakan.

\section{Indikator Keberhasilan}

Indikator keberhasilan dalam penelitian ini apabila minimal $75 \%$ dari jumlah anak didik kriteria ketuntasan yang telah ditentukan oleh peneliti. Anak yang telah memperoleh angka 4 berarti telah memenuhi kriteria tuntas sempurna. Sedangkan anak yang mampu mencapai kriteria dengan nilai 3 berarti anak telah memenuhi kriteria tuntas. Kemudian bagi anak yang memperoleh nilai 1 dan 2 berarti anak tersebut belum 
mencapai kriteria tuntas dan aspek indikator yang diharapkan belum dapat dicapai oleh anak. Angka keberhasilan $75 \%$ itu didapat dari anak yang memperoleh nilai 4 dan 3.

\section{HASIL DAN PEMBAHASAN Siklus I}

\section{Tabel 1.}

Ciri-ciri Ayam yang Lain yang Ditemukan Anak Berdasarkan Pengamatan dan Pengalaman Anak

\begin{tabular}{|c|c|c|}
\hline No & Nama & Ciri ayam yang lain yang di temukan anak \\
\hline 1. & Andika & Tidak punya gigi, kukunya panjang, jarinya 4. \\
\hline 2. & Fajar & Telinganya kecil, hidungnya nempel di cucuk, bisa terbang dikit \\
\hline 3. & Imel & $\begin{array}{l}\text { Kalau minum sambil lihat ke atas (ndengak), ayam jantan kalau bersuara juga lihat ke } \\
\text { atas, lidahnya lancip. }\end{array}$ \\
\hline 4. & Jihan & $\begin{array}{l}\text { Suara ayam jantan lebih keras dari ayam betina,kakinya selain untuk jalan juga untuk } \\
\text { mencari makan. }\end{array}$ \\
\hline 5. & Neka & Rumahnya dikandang, ayam jago suka berantem, lehernya agak panjang. \\
\hline 6. & Raisya & Bau tidak pernah mandi, cara panggil ayam ker ker ker. \\
\hline 7. & Rahmad & Bulunya bisa buat kok main bulu tangkis. \\
\hline 8. & Ayisah & Ayam jantan bangunnya lebih pagi karena kukuruyuk bangunin orang-orang. \\
\hline 9. & Dera & Ayam kalau mau bertelur berisik. \\
\hline
\end{tabular}

Berdasarkan pelaksanaan siklus 1, dari 19 anak ada yang sudah mencapai kemampuan maksimal walaupun masih beberapa anak saja. Persentase ketercapaian anak dalam pengetahuan sainsnya sebanyak $41 \%$ dengan demikian telah terjadi peningkatan $10 \%$ dari yang semula $31 \%$ pada pra siklus atau sebelum dilakukan tindakan. Walaupun sudah menunjukan perubahan yang meningkat namun masih dibutuhkan tindakan lagi pada siklus II supaya mencapai indikator keberhasilan.

Beberapa hal yang perlu diperhatikan dan untuk dilakukan perbaikan dalam pelaksanaan siklus 1 yaitu penguasaan materi oleh guru yang sangat mempengaruhi utamanya untuk merangsang anak dalam pengatahuannya dan teknik penggunaan metode eksplorasi lingkungan sekitar untuk lebih membebaskan lagi dalam bereksplorasi.

\section{Aktivitas Anak Didik dalam Pengetahuannya mengenai Sains dengan Eksplorasi Lingkungan Sekitar Pada Siklus I \\ Berikut ini hasil tebel pengamatan kegiatan Eksplorasi Lingkungan Sekitar meneliti ayam.}

Tabel 2. Data Hasil Pengamatan Kegiatan Eksplorasi Lingkungan Sekitar Meneliti Ayam

\begin{tabular}{|c|c|c|c|c|c|c|c|}
\hline \multirow{2}{*}{ Indikator } & \multirow{2}{*}{ Sub Indikator } & \multicolumn{4}{|c|}{ Nilai } & \multirow{2}{*}{ Jumlah Yang Tuntas } & \multirow{2}{*}{$\%$} \\
\hline & & 1 & 2 & 3 & 4 & & \\
\hline $\begin{array}{l}\text { Identifikasi berdasarkan ciri- } \\
\text { ciri objek. }\end{array}$ & $\begin{array}{l}\text { Menyebutkan sebanyak- } \\
\text { banyaknya ciri-ciri ayam }\end{array}$ & 4 & 5 & 5 & 5 & 10 & $53 \%$ \\
\hline Mengklasifika sikan objek & $\begin{array}{l}\text { Anak dapat menyebutkan } \\
\text { persamaan antara ayam jantan } \\
\text { dan ayam betina. }\end{array}$ & 5 & 6 & 5 & 3 & 8 & $42 \%$ \\
\hline sesuai dengan pengamatan. & $\begin{array}{l}\text { Anak dapat menyebutkan } \\
\text { perbedaan antara ayam jantan } \\
\text { dan ayam betina. }\end{array}$ & 6 & 4 & 5 & 4 & 9 & $47 \%$ \\
\hline & $\begin{array}{l}\text { Menemukan ide ciri ayam } \\
\text { penemuannya sendiri }\end{array}$ & 10 & 3 & 2 & 4 & 6 & $32 \%$ \\
\hline $\begin{array}{l}\text { Pengetahuan orisinil dar1 } \\
\text { eksplorasi lingkungan sekitar }\end{array}$ & $\begin{array}{l}\text { Anak mampu menceritakan } \\
\text { pengetahuannya saat mengamati } \\
\text { ayam }\end{array}$ & 9 & 4 & 2 & 4 & 6 & $32 \%$ \\
\hline
\end{tabular}

Keterangan nilai:

$1=$ tidak mampu

2 = cukup mampu

$3=$ mampu

4 = sangat mampu 
Pada proses pembelajaran pada siklus 1 dengan kegiatan meneliti ayam jantan dan ayam betina melalui penerapan metode eksplorasi lingkungan sekitar yang menyebutkan sebanyak-banyaknya ciri-ciri ayam ada 53\%, anak yang menyebutkan persamaan antara ayam jantan dan ayam betina ada $42 \%$, anak yang menyebutkan perbedaan antara ayam jantan dan ayam betina ada $47 \%$, anak yang memiliki pengetahuan orisinil dengan menemukan ide ciri ayam yang ditemukan anak ada $32 \%$ dan anak mampu menceritakan pengetahuannya saat mengamati ayam ada 32\%. Atau bisa dilihat dalam bentuk grafik sebagai berikut:

\title{
Data Hasil Pengamatan Kegiatan Eksplorasi Lingkungan Sekitar Meneliti Ayam Siklus I
}

\author{
Menceritakan Pengetahuan Saat \\ Mengamati Ayam \\ Ciri Lain yang ditemukan Anak \\ Perbedaan Ayam \\ Persamaan Ayam \\ Ciri-Ciri Ayam
}

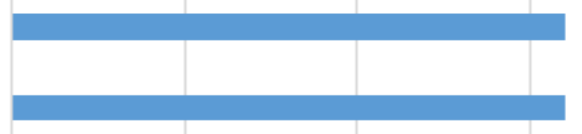

$\mathrm{O} \%$

$10 \% \quad 20 \%$

$30 \%$

$40 \%$

$50 \%$

$60 \%$

- Data Hasil Pengamatan Kegiatan Eksplorasi Lingkungan Sekitar Meneliti Ayam

\section{Gambar 1}

\section{Data Hasil Pengamatan Kegiatan Eksplorasi Lingkungan Sekitar Meneliti Ayam Siklus I}

Dari hasil ini masih perlu dilakukan tindakan pada sikluss II. Hal ini karena keaktifan anak-anak dalam mengkaji pengetahuan nya masih rendah.

\section{Siklus II}

\section{Tabel 4}

\section{Ciri-ciri Kucing yang Lain yang Ditemukan Anak Berdasarkan Pengamatan dan Pengatahuannya.}

\begin{tabular}{lll}
\hline No & \multicolumn{1}{c}{ Nama } & \multicolumn{1}{c}{ Ciri kucing yang lain yang di temukan anak } \\
\hline 1. & Andika & Kumisnya kanan kiri, ada giginya, bisa manjat. \\
2. & Fajar & Anaknya banyak, jarinya 5, suka menjilati bulunya. \\
3. & Imel & Suka berantem, matanya menyala saat terkena lampu, kucing yang warnanya hitam menakutkan. \\
4. & Jihan & Gendong anaknya dengan mengigit leher atas (tengkuk), kucing ada yang warnanya belang-belang. \\
5. & Neka & Kadang-kadang suaranya seperti suara bayi menangis. \\
6. & Raisya & Mengubur kotorannya, suka dibelai-belai, kalau minum lidahnya keluar. \\
7. & Rahmad & Suka bermanja-manja (ngusel-ngusel), menggaruk- garukan kukunya ke pohon, cara memanggil pus pus. \\
8. & Nadiah & Suka naik ke atas rumah, kalau jalan ekornya goyang- goyang \\
9. & Ayisah & Kalau lari cepet, matanya bunder banget. \\
10. & Dera & Kucing suka jalan-jalan malam hari, kukunya panjang. \\
11. & Muhammad & Kumisnya warnanya putih, hidungnya pesek. \\
12. & Habibi & Kucing ada yang warna putih, coklat, dan hitam. \\
13. & Rahmadon & Bulunya bisa menjadi penyakit. \\
14. & Ririn & Kucing binatang lucu. \\
\hline
\end{tabular}

Hasil pelaksanaan tindakan pada siklus II sudah lebih baik dari siklus 1. Persentase ketercapaian anak dalam pengetahuan sains sebanyak 59\%, artinya ada peningkatan pengetahuan sains anak didik sebesar $18 \%$ dari yang semula $41 \%$ pada siklus I. Namun hasil dari siklus II ini masih harus di tindak lanjuti dengan pemberian tindakan. Jadi masih dibutuhkan tindakan yang ketiga atau siklus III, karena belum mencapai 
indikator keberhasilan batas minimal atau diharapkan lebih dari 75\% anak-anak TK Kelompok B ini mempunyai pengetahuan sains yang baik. Keaktifan anak pada siklus II masih perlu ditingkatkan pada siklus III dan guru harus lebih aktif untuk memotivasi anak.

\section{Aktivitas Anak Didik dalam Kegiatan Belajar Mengajar Siklus II}

Hasil pengamatan terhadap aktivitas anak didik dalam pengetahuan sains dengan metode eksplorasi lingkungan sekitar dinyatakan dengan presentase. Perhatikan tabel berikut ini :

\section{Tabel 5}

Data Hasil Pengamatan Kegiatan Eksplorasi Lingkungan Sekitar Meneliti Kucing pada Siklus II

\begin{tabular}{|c|c|c|c|c|c|c|c|}
\hline \multirow{2}{*}{ Indikator } & \multirow{2}{*}{ Sub Indikator } & \multicolumn{4}{|c|}{ Nilai } & \multirow{2}{*}{ Jumlah Tuntas } & \multirow{2}{*}{$\%$} \\
\hline & & 1 & 2 & 3 & 4 & & \\
\hline $\begin{array}{l}\text { Identifikasi berdasarkan ciri- } \\
\text { ciri objek. }\end{array}$ & $\begin{array}{l}\text { Menyebutkan sebanyak- banyaknya } \\
\text { ciri- ciri kucing. }\end{array}$ & 4 & 2 & 5 & 8 & 13 & $68 \%$ \\
\hline Mengklasifika sikan objek & $\begin{array}{l}\text { Anak dapat menyebutkan persamaan } \\
\text { kucing jantan dan betina. }\end{array}$ & 3 & 6 & 2 & 8 & 10 & $53 \%$ \\
\hline sesuai dengan pengamatan & $\begin{array}{l}\text { Anak dapat menyebutkan perbedaan } \\
\text { kucing jantan dan betina. }\end{array}$ & 2 & 5 & 5 & 7 & 12 & $63 \%$ \\
\hline & $\begin{array}{l}\text { Menemukan ide ciri kucing } \\
\text { penemuannya sendiri }\end{array}$ & 5 & 3 & 6 & 5 & 11 & $58 \%$ \\
\hline $\begin{array}{l}\text { Pengetahuan orisinil darı } \\
\text { eksplorasi lingkungan sekitar }\end{array}$ & $\begin{array}{l}\text { Anak mampu menceritakan } \\
\text { pengetahuannya saat mengamati } \\
\text { kucing }\end{array}$ & 7 & 2 & 2 & 8 & 10 & $53 \%$ \\
\hline
\end{tabular}

Keterangan nilai:

$1=$ tidak mampu

2 = cukup mampu

$3=$ mampu

$4=$ sangat mampu

Pada proses pembelajaran pada siklus II dengan kegiatan meneliti kucing jantan melalui penerapan metode eksplorasi lingkungan sekitar yang menyebutkan sebanyak-banyaknya ciri-ciri kucing ada $68 \%$, anak yang menyebutkan persamaan antara kucing jantan dan kucing betina ada 53\%, anak yang menyebutkan perbedaan antara kucing jantan dan kucing betina ada 63\%, anak yang memiliki pengetahuan orisinil dengan menemukan ide ciri kucing yang ditemukan anak ada 58\% dan yang menceritakan pengetahuannya ada 53\%. Dapat di lihat melalui grafik sebagai berikut :

\section{Data Hasil Pengamatan Kegiatan Eksplorasi Lingkungan Sekitar Meneliti Kucing Siklus II}

Menceritakan Pengetahuan Saat Mengamati Kucing

Ciri Lain yang ditemukan Anak

Perbedaan Kucing

Persamaan Kucing

Ciri-Ciri Kucing

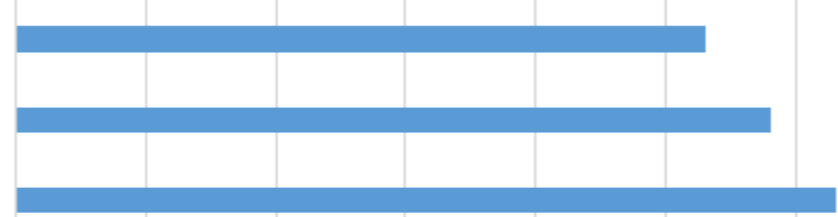

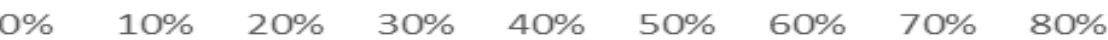

- Data Hasil Pengamatan Kegiatan Eksplorasi Lingkungan Sekitar Meneliti Kucing

\section{Gambar 2}


Terdapat peningkatan disemua bagian sub indikator yang telah diamati dari sik lus sebelumnya. Hal ini menunjukkan bahwa keaktifan anak didik dala m mengikuti pembelajaran di suklus II khusus nya dalam pengetahuan sai ns sudah lebih baik.

Anak-anak sangat antusias untuk melakukan kegiatan meneliti binatang. Mereka juga terlatih untuk menjadi seorang peneliti, yang menggali pengetahuan, menambah pengetahuan dan mendapatkan pengetahuan ya ng baru untuk pengalamannya. Dari sini juga anak akan terbiasa memec ahkan masalah dengan tidak tergesa-gesa, tetapi dengan meneliti terlebih dahulu masalah itu dan memecahkannya berdasarkan fakta yang ada.

Keaktifan anak dalam mengikuti KBM pada siklus II memang sudah baik, namun masih dijumpai 8 anak yang masih pasif. Hal ini berarti guru lebih berusaha keras untuk meningkatkan lagi dalam merangsang anak tersebut supaya aktif dalam KBM.

\section{Siklus III}

\section{Tabel 6}

Ide Ciri-ciri Ikan dan sapi yang Lain yang Ditemukan Anak Berdasarkan Pengamatan dan Pengatahuannya

\begin{tabular}{|c|c|c|}
\hline No & Nama & Ciri ikan dan sapi yang lain yang di temukan anak \\
\hline 1. & Andika & Sama-sama bisa dijual, sapi menghasilkan susu kalau ikan tidak, gigi sapi besar-besar. \\
\hline 2. & Fajar & Kaki sapi tidak ada jarinya, ikan tidak bisa kunyah- kunyah, matanya besar mata sapi. \\
\hline 3. & Imel & $\begin{array}{l}\text { Sama-sama kalau dimasak enak, sama-sama badannya ada yang belang-belang, ikan ada durinya kalau } \\
\text { sapi tidak. }\end{array}$ \\
\hline 4. & Jihan & Banyak anaknya ikan dari pada sapi, sapi ada telinganya kalau ikan tidak, ikan kalau didarat bisa mati. \\
\hline 5. & Neka & Ikan biasanya dipancing, ekor sapi ada rambutnya, sapi bisa jadi binatang korban. \\
\hline 6. & Raisya & Dagingnya banyak sapi daripada ikan, ikan baunya amis, ikan tidak bisa kunyah-kunyah. \\
\hline 7. & Rahmad & Ikan tidak bisa merem, ikan suka lari berenang di kolam, sapi kalau ntidak dikandang menakutkan. \\
\hline 8. & Nadiah & Sapi pipis dan bab sambil berdiri, mulut ikan buka tutup, tubuh ikan licin. \\
\hline 9. & Ayisah & Dagingnya bisa dibuat bakso, sapi lebih berat dari pada ikan, rumah sapi kandang. \\
\hline 10. & Dera & Rumah ikan kolam, ikan dilihat indah. \\
\hline 11. & Muhammad & Telur ikan dimasak enak, ikan telurnya banyak. \\
\hline 12. & Habibi & Ikan tidak ada suaranya, kalau di obok-obok airnya ikan bisa mati. \\
\hline 13. & Rahmadon & Sapi ada lidahnya kalau ikan tidak, sapi ada lehernya kalua ikan tidak. \\
\hline 14. & Ririn & Sapi bisa nyrudug, sapi ada hidungnya kalau ikan tidak. \\
\hline 15. & Peli & Matanya ada dua semua, kalau makan sama-sama pakai mulut \\
\hline 16. & Rafiqah & Sapi bisa duduk. \\
\hline 17. & Chahya & Ikan dan sapi tidak suka suka berantem. \\
\hline 18. & Nazwa & Sapi lebih suka diem. \\
\hline
\end{tabular}

Dari 19 anak didik yang telah mengikuti kegiatan eksplorasi lingkungan sekitar pada siklus III ini dapat mengikuti dengan baik. Pada kegiatan meneliti ikan dan sapi pada siklus III sebanyak 89\% atau 17 anak sudah dapat menunjuk dan menyebutkan sebanyak-banyaknya ciri-ciri. Hal ini menunjukkan bahwa penggunaan metode eksplorasi lingkungan sekitar dalam kegiatan belajar mengajar telah dapat meningkatkan kemampuan anak didik TK Putra I Kota Jambi dalam pengetahuan sains. Keberhasilan memecahkan masalah yang terjadi pada kelompok B TK Putra I Kota Jambi ini tidak lepas dari kemampuan guru dalam menggunakan metode eksplorasi lingkungan sekitar. Pada siklus ini guru sudah baik dalam menyusun, perencanaan, melaksanakan dan mengevaluasi dengan baik pada kegiatan bermain dan belajar dengan metode eksplorasi lingkungan sekitar.

\section{Aktivitas anak didik dalam pengetahuan sains dalam KBM}

Hasil pengamatan terhadap aktivitas anak didik dalam pengetahuan sains pada proses pembelajaran siklus III adalah sebagai berikut : 
Tabel 7

Data Hasil Pengamatan Kegiatan Eksplorasi Lingkungan Sekitar Meneliti Ikan dan sapi pada Siklus III

\begin{tabular}{|c|c|c|c|c|c|c|c|}
\hline \multirow{2}{*}{ Indikator } & \multirow{2}{*}{ Sub Indikator } & \multicolumn{4}{|c|}{ Nilai } & \multirow{2}{*}{$\begin{array}{c}\text { Jumlah Yang } \\
\text { Tuntas }\end{array}$} & \multirow{2}{*}{$\%$} \\
\hline & & 1 & 2 & 3 & 4 & & \\
\hline $\begin{array}{l}\text { Identifikasi erdasarkan } \\
\text { ciri-ciri objek. }\end{array}$ & $\begin{array}{l}\text { Menyebutkan sebanyak- banyaknya ciri- ciri } \\
\text { ikan dan sapi. }\end{array}$ & 1 & 1 & 8 & 9 & 17 & $89 \%$ \\
\hline Mengklasifika sikan & $\begin{array}{l}\text { Anak dapat menyebutkan persamaan antara } \\
\text { ikan dan sapi. }\end{array}$ & 1 & 2 & 7 & 9 & 16 & $84 \%$ \\
\hline pengamatan & $\begin{array}{l}\text { Anak dapat menyebutkan perbedaan antara } \\
\text { ikan dan sapi. }\end{array}$ & 1 & 2 & 6 & 10 & 16 & $84 \%$ \\
\hline Pengetahuan orisinil dari & $\begin{array}{l}\text { Menemukan ide ciri ikan dan sapi } \\
\text { penemuannya sendiri }\end{array}$ & 1 & 3 & 6 & 9 & 15 & $79 \%$ \\
\hline $\begin{array}{l}\text { eksplorasi lingkungan } \\
\text { sekitar }\end{array}$ & $\begin{array}{l}\text { Anak mampu menceritakan pengetahuannya } \\
\text { saat mengamati ikan dan sapi. }\end{array}$ & 1 & 3 & 7 & 8 & 15 & $79 \%$ \\
\hline
\end{tabular}

Keterangan nilai:

$1=$ tidak mampu

2 = cukup mampu

$3=$ mampu

$4=$ sangat mampu

Anak-anak didik terangsang untuk menggali pengetahuannya selama kegiatan belajar mengajar. Hampir semua anak meningkat pengetahuannya mengenai sains dengan metode eksplorasi lingkungan sekitar. Dapat dilihat dalam grafik berikut:

\section{Data Hasil Pengamatan Kegiatan Eksplorasi Lingkungan Sekitar Meneliti Ikan dan Sapi Siklus III}

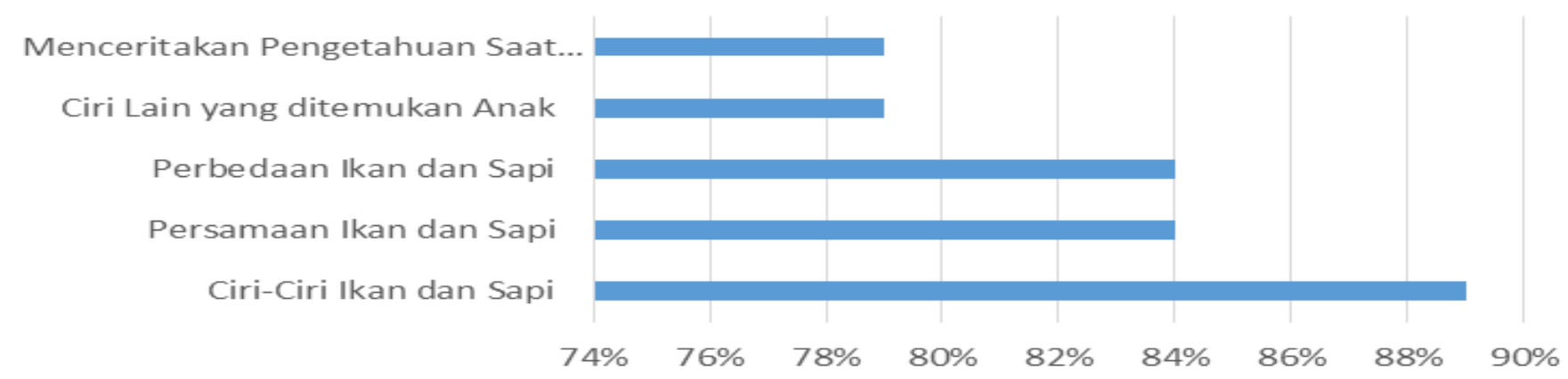

- Data Hasil Pengamatan Kegiatan Eksplorasi Lingkungan Sekitar Meneliti Ikan dan Sapi

\section{Gambar 3}

\section{Data Hasil Pengamatan Kegiatan Eksplorasi Lingkungan Sekitar Meneliti Ikan dan sapi pada Siklus III}

Pada ke giatan siklus III ini anak semangat dan tertarik untuk meneliti ikan dan sapi karena anak ingin segera mengetah ui dengan meneliti binatang tersebut mengenai perbedaan ciri-ciri antara ikan dan sapi. Mereka da pat dengan mudah menemukan perbedaan ciri-ciri ikan dan sapi denga $\mathrm{n}$ melihat langsung binatang yang diamati. Ti dak hanya mudah menemukan perbedaan ciri-ciri ikan dan sapi tetapi mereka juga sangat senang bisa bermain-main dengan binatang tersebu t. Dengan perasaan yang s enang dengan suasana yang bebas bereksplorasi, maka anak menjadi ter asah kemampuannya untuk menambah pengeta huan sains mereka. 


\section{Pembahasan}

Penggunaan metode eksplorasi lingkungan sekitar dalam pembelajaran di Taman Kanak-kanak Putra I Kota Jambi di lakukan selama tiga siklus. Perkembangan anak-anak didik dalam pengetahuannya mengenai sains dapat dilihat pada tabel hasil penelitian siklus I, II dan III berikut ini :

\section{Tabel 8}

\section{Data Hasil Pengamatan Kegiatan Belajar Mengajar dengan Metode Eksplorasi Lingkungan Sekitar} pada Siklus I, Siklus II dan Siklus III

\begin{tabular}{llccc}
\hline \multicolumn{1}{c}{ Indikator } & \multicolumn{1}{c}{ Sub Indikator } & Siklus I & Siklus II & Siklus III \\
\hline $\begin{array}{l}\text { Identifikasi berdasarkan ciri-ciri } \\
\text { objek. }\end{array}$ & Menyebutkan sebanyak- banyaknya ciri-ciri objek & $53 \%$ & $68 \%$ & $89 \%$ \\
$\begin{array}{l}\text { Mengklasifika sikan objek } \\
\text { sesuai dengan pengamatan }\end{array}$ & Anak dapat menyebutkan persamaan antar objek & $42 \%$ & $53 \%$ & $84 \%$ \\
Pengetahuan orisinil dari & Anak dapat menyebutkan perbedaan antar objek & $47 \%$ & $63 \%$ & $84 \%$ \\
eksplorasi lingkungan sekitar & $\begin{array}{l}\text { Menemukan ide ciri objek penemuannya sendiri } \\
\text { Anak mampu menceritakan pengetahuannya }\end{array}$ & $32 \%$ & $58 \%$ & $79 \%$ \\
& mengamati objek & $32 \%$ & $53 \%$ & $79 \%$ \\
\hline
\end{tabular}

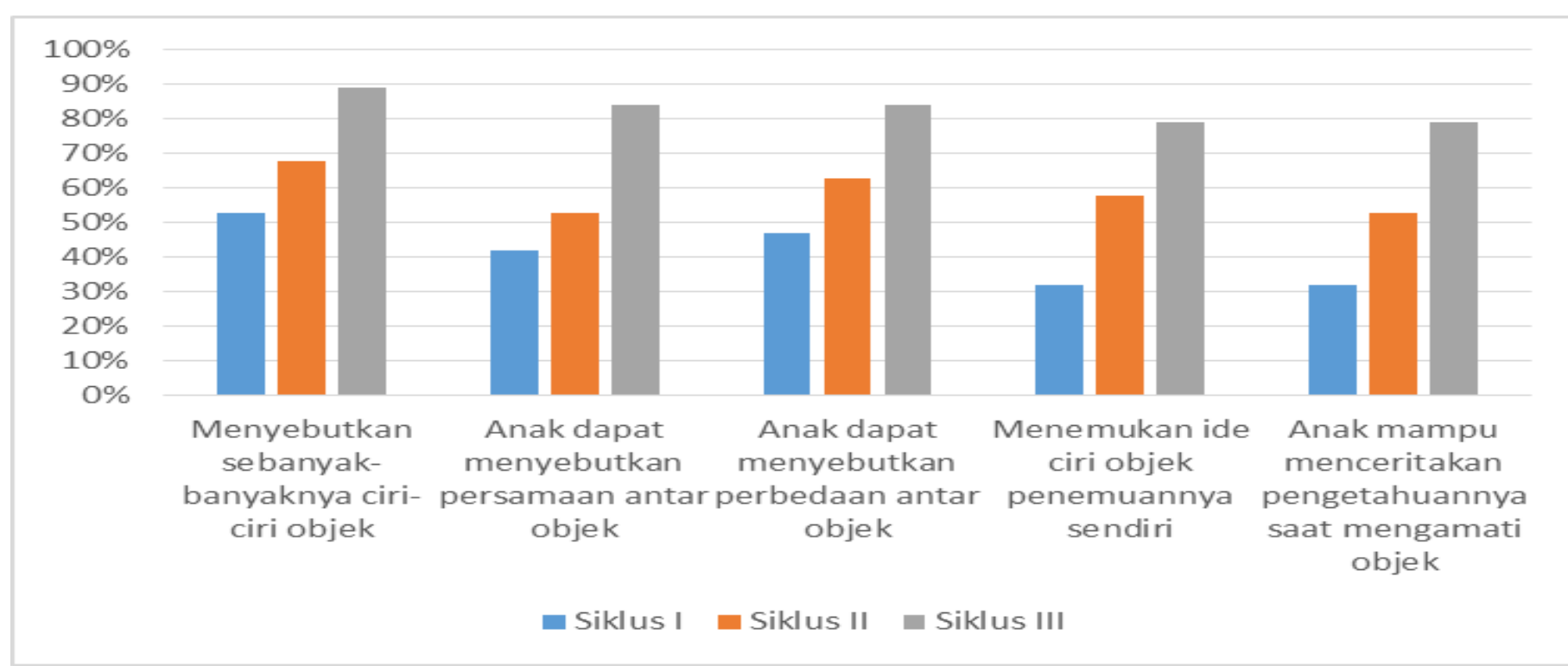

\section{Gambar 4}

Data Hasil Pengamatan Kegiatan Belajar Mengajar dengan Metode Eksplorasi Lingkungan Sekitar pada Siklus I, Siklus II dan Siklus III

\section{SIMPULAN}

1. Peningkatan pengetahuan sains anak didik TK Putra I Kota Jambi melalui pembelajaran dengan metode eksplorasi lingkungan sekitar telah dibuktikan dengan hasil pengamatan pada keaktifan anak didik dalam mengemukakan pengetahuan sainsnya pada siklus I, siklus II dan siklus III. Pada siklus I anak yang menyebutkan sebanyak-banyaknya ciri-ciri ayam ada 53\%, anak yang menyebutkan persamaan antara ayam jantan dan ayam betina ada $42 \%$, anak yang menyebutkan perbedaan antara ayam jantan dan ayam betina ada 47\%, anak yang memiliki pengetahuan orisinil dengan menemukan ide ciri ayam yang ditemukan anak ada 32\% dan anak yang mampu menceritakan pengetahuannya mengenai ayam ada $32 \%$. Pada siklus II anak yang menyebutkan sebanyak-banyaknya ciri-ciri kucing ada 68\%, anak yang menyebutkan persamaan antara kucing jantan dan kucing betina ada 53\%, anak yang menyebutkan perbedaan antara kucing jantan dan kucing betina ada 63\%, anak yang memiliki pengetahuan orisinil dengan menemukan ide ciri kucing yang ditemukan anak ada $58 \%$ dan anak yang mampu menceritakan pengetahuannya mengenai kucing ada 53\%. Pada siklus III anak yang menyebutkan sebanyak-banyaknya ciri-ciri ikan dan sapi ada $89 \%$, anak yang menyebutkan persamaan antara ikan dan sapi ada $84 \%$, anak yang menyebutkan perbedaan antara ikan dan sapi ada $84 \%$, anak yang memiliki pengetahuan orisinil 
dengan menemukan ide ciri ikan dan sapi yang ditemukan anak ada $79 \%$ dan anak yang mampu menceritakan pengetahuannya mengenai ikan dan sapi ada $79 \%$.

2. Kemampuan guru dalam mengajar dengan metode eksplorasi lingkungan sekitar pada siklus I, siklus II dan siklus III mendapatkan kategori baik penerapan pada anak didik, sehingga pada penelitian ini guru berhasil menerapkan metode ini.

3. Anak-anak TK Putra I Kota Jambi terlihat mudah menyebutkan pengetahuan sainsnya dengan pembelajaran melalui metode eksplorasi lingkungan sekitar.

4. Berdasarkan pengamatan dari siklus I, siklus II dan siklus III dapat disimpulkan bahwa metode eksplorasi lingkungan sekitar dapat meningkatkan pengetahuan sains anak didik TK Putra I Kota Jambi.

\section{DAFTAR PUSTAKA}

Hurlock,ElizabethB.1997.Perkembangan Anak jilid1. Jakarta:Erlangga.

Sujiono, Yuliani Nurani dkk. 2006. Metode Pengembangan Kognitif. Jakarta: Universitas Terbuka. Tim Redaksi Ayahbunda. 2002. Dari A sampai Z tentang Perkembangan Anak. Jakarta : PT Gaya Favorit Press.

R, Moeslichatoen M.Pd. 1995. Metode Pengajaran di Taman Kanak-kanak. Jakarta : Departemen Pendidikan dan Kebudayaan.

Jamaris, Martini. 2003. Perkembangan dan Pengembangan Anak Usia Taman Kanak-kanak. Jakarta :

Program Studi Pendidikan Usia Dini PPS Universitas Negeri Jakarta.

Masitoh. 2007. Strategi Pembelajaran TK. Jakarta : Universitas Terbuka.

Poedjiadi, Anna. 2007. Filsafat Ilmu. Jakarta : Universitas Terbuka.

Fried, George H. 2005. Schaum's Outlines Biologi Edisi Kedua. Jakarta: Erlangga.

Wijana,WidarmiD.2008.Kurikulum Pendidikan Anak Usia Dini. Jakarta : Universitas Terbuka.

Arikunto, Suharsimi. (2002). Dasar-dasar Evaluasi Pendidikan. Jakarta : Bumi Aksara. 